\section{Variable Reaction of Tomato Lines to Bacterial Wilt Evaluated at Several Locations in Southeast Asia}

\author{
Peter M. Hanson and Jaw-Fen Wang \\ Asian Vegetable Research and Development Center, Box42, Shanhua, Tainan, \\ Taiwan 741, Republic of China \\ Olivia Licardo \\ Institute of Plant Breeding, University of the Philippines College, \\ Laguna, Philippines
}

\author{
Hanudin \\ Segunung Horticultural Research Station, P.O. Box 8, Sindanglaya, Cianjur \\ 43253 West Java, Indonesia
}

\author{
Shook Ying Mah \\ Malaysian Agricultural Research and Development Institute, Jalan Kebun, \\ Selangor, Kuala Lumpur, Malaysia \\ Glen L. Hartman ${ }^{1}$, Yuan-Chuen Lin, and Jen-tzu Chen \\ Asian Vegetable Research and Development Center, Box42, Shanhua, Tainan, \\ Taiwan 741, Republic of China
}

Additional index words. Lycopersicon esculentum, Pseudomonas solanacearum, resistance

\begin{abstract}
Bacterial wilt (BW), caused by Pseudomonas solanacearum E.F. Smith, is one of the most destructive disease of tomato (Lycopersicon esculentum Mill.) in the tropics. Twenty tomato lines/accessions previously identified as BW-resistant were evaluated for BW reaction in fields providing high disease pressure at Subang, Indonesia; Los Baños, Philippines; Malaysian Agricultural Research and Development Institute (MARDI), Kuala Lumpur; Asian Vegetable Research and Development Center (AVRDC), Taiwan; and Taiwan Seed Improvement and Propagation Service (TSIPS). Entries also were tested in the greenhouse at the AVRDC with a $P$. solanacearum strain from Taiwan (Pss4) using a drench inoculation method. Objectives of the study were to identify stable sources of $B W$ resistance for southeast Asian tomato breeding programs, and to determine the correlation between field and greenhouse reactions. Mean entry survival was $21.6 \%$ at Subang, 31.9\% at Los Baños, 76.7\% at the AVRDC, 93.6\% at Malaysia, and 93.3\% at TSIPS, indicating that most entries were resistant at MARDI and the Taiwan locations but susceptible at Subang and Los Baños. L285 (mean survival $=83.8 \%$ ) and CRA 84-58-1 (mean survival $=\mathbf{7 9 . 4 \%}$ ) were the most resistant entries in the field trials. Mean survival (70.1\%) of CRA 66-derived entries was significantly better than the mean of entries with resistance derived from UPCA 1169 or UPCA 1169 plus 'Venus' or 'Saturn'. Mean survival of AVRDC entries bred in the $1980 \mathrm{~s}(59.4 \%)$ was significantly greater than mean survival of AVRDC lines bred in the 1970s $(45.7 \%)$. The correlation between entry BW percent survival averaged over the five field trials and entry means from drench inoculation in the greenhouse was highly significant $(r=0.70)$, suggesting that the drench inoculation method is effective in selection for $B W$ resistance.
\end{abstract}

Bacterial wilt (BW) of tomato, caused by Pseudomonas solanacearum E.F. Smith, is one of the most important diseases in the

Received for publication 28 Aug. 1995. Accepted for publication 26 Sept. 1995. Journal paper no. 152 of the Asian Vegetable Research and Development Center. This research was funded by the Asian Development Bank and the Asian Vegetable Research and Development Center. The cost of publishing this paper was defrayed in part by the payment of page charges. Under postal regulations, this paper therefore must be hereby marked advertisement solely to indicate this fact.

${ }^{1}$ Current address: U.S. Dept. of AgricultureAgricultural Research Service, Univ. of Illinois, Urbana, IL 61801.

tropics, and it severely limits tomato production in many tropical and subtropical regions (Opeña et al., 1990). Disease control is difficult because of the broad host range, widespread distribution, and vast genetic variability of $P$. solanacearum (Hayward, 1991). Identifying BW resistance sources and combining $\mathrm{BW}$ resistance with other traits, such as hightemperature fruit set, that are critical to tropical adaptation have been objectives of the Asian Vegetable Research and Development Center (AVRDC) Tomato Improvement Project since its inception in 1972 (Opeña et al., 1990).

AVRDC tomato lines have been widely distributed in southeast Asia, but some lines selected for BW resistance in Taiwan were susceptible when grown at some other locations (AVRDC, 1992; Yang, 1979). Reasons for inconsistent $\mathrm{BW}$ reactions may be due to pathogen strain differences (Elphinstone, 1994; Prior et al., 1990) or environmental effects on the host and pathogen (Hayward, 1991; Krausz and Thurston, 1975; Libman et al., 1964; Messiaen, 1989).

Several tomato breeding programs in various areas of the world have developed BWresistant germplasm using differing resistance sources. North Carolina State Univ. released commercial cultivars Venus and Saturn with resistance obtained from PI129080 [ $L$. pimpinellifolium (Jusl.) Mill.] and Beltsville \#3814 (Henderson and Jenkins, 1972). Another L. pimpinellifolium accession, PI127805A, was the source of BW resistance in tomato lines, such as 'Kewalo', Hawaii 7997, and Hawaii 7998, released from the Univ. of Hawaii (Gilbert et al., 1973; Scott et al., 1993). CRA66, a small-fruited, BW-resistant indeterminate from the Caribbean, was exploited by the Institut National de la Recherche Agronomique (INRA) Guadeloupe, French West Indies, to develop BW-resistant cultivars Caraïbo and Carmido (Grimault et al., 1993). Jaworski et al. (1987) evaluated $>2000$ Lycopersicon accessions for BW reaction and selected resistant plants from PI263722 ( $L$. esculentum), PI126408 (L. esculentum), PI196298 (L. esculentum), and PI251323 (L. pimpinellifolium).

Evaluation of BW-resistant tomato germplasm over many environments is considered to be the most effective strategy to identify the best sources of BW resistance (Chellemi et al., 1994; Grimault et al., 1994; Scott et al., 1993). Recognizing the advantage of a regional approach to $\mathrm{BW}$ research, we collaborated to assemble and test BW-resistant tomato accessions/lines derived from several resistance sources as part of the Collaborative Vegetable Research Program in southeast Asia. Objectives of this study were to identify stable sources of BW resistance for tomato breeding programs in southeast Asia, and to determine the correlation between field and greenhouse $\mathrm{BW}$ reactions.

\section{Materials and Methods}

Entries. Twenty tomato accessions/lines previously identified as BW-resistant (Table 1) were chosen for multi-location BW evaluations. Entries derived from several resistance sources were included (Table 1). Eleven entries were from the AVRDC: CL 1131-0-013-0-6 (CL 1131), CL 143-0-10-3-0-1-10 (CL 143), CL 8d-0-7-1 (CL 8), CL 9-0-0-1-3 (CL 9), CL 11d-0-2-1 (CL 11), CL 5915-93D-1-0-3 (CL 5915-93), CL 5915-206D $4-2-2-0$ (CL 5915-206), CL 6047-1-1-2-3-2-7-0 (CL 6047), CLN 475BC $\mathrm{B}_{2}-265-4-19$ (CLN 475), CLN 65-349D $5_{5}-2-0$ (CLN 65), CLN 657-BC $\mathrm{B}_{1} \mathrm{~F}_{2}$ 285-0-21-0 (CLN 657); five entries were developed by INRA in the Guadeloupe; and L285 is a small-fruited landrace L. esculentum var. cerasiforme from Kangshan, Taiwan (AVRDC, 1978). MT5 and MT10 were se- 
Breeding, Cultivars, Rootstocks, \& Germplasm Resources

Table 1. Tomato accessions/lines evaluated for bacterial wilt reaction in southeast Asia.

\begin{tabular}{|c|c|c|c|}
\hline Entry & Origin $^{z}$ & Plant habit ${ }^{y}$ & Resistance source \\
\hline MT5 & MARDI & $\mathrm{sp}$ & $--^{x}$ \\
\hline MT10 & MARDI & sp & $--^{x}$ \\
\hline $\operatorname{Tm} 2$ & BPI & $\mathrm{sp}$ & Unknown \\
\hline L285 & AVRDC & $\mathrm{sp}^{+}$ & Taiwan landrace \\
\hline CRA $84-79$ & INRA & $\mathrm{sp}$ & CRA 66 \\
\hline CRA 84-58-1 & INRA & $\mathrm{sp}$ & CRA 66 \\
\hline CRA 84-6-3 & INRA & $\mathrm{sp}$ & CRA 66 \\
\hline CRA 84-26-3 & INRA & $\mathrm{sp}$ & CRA 66 \\
\hline Caraïbo & INRA & $\mathrm{sp}$ & CRA 66 \\
\hline CL $1131^{\mathrm{w}}$ & AVRDC & $\mathrm{sp}$ & UPCA $1169^{v}$ \\
\hline CL 143 & AVRDC & $\mathrm{sp}$ & UPCA 1169 \\
\hline CL 8 & AVRDC & $\mathrm{sp}$ & Venusv, UPCA 1169 \\
\hline CL 9 & AVRDC & $\mathrm{sp}$ & Saturn", UPCA 1169 \\
\hline CL 11 & AVRDC & $\mathrm{sp}$ & Venus, UPCA 1169 \\
\hline CL 5915-93 & AVRDC & $\mathrm{sp}$ & Saturn, UPCA 1169 \\
\hline CL 5915-206 & AVRDC & $\mathrm{sp}^{+}$ & Saturn, UPCA 1169 \\
\hline CL 6047 & AVRDC & $\mathrm{sp}$ & UPCA 1169 \\
\hline CLN 475 & AVRDC & $\mathrm{sp}$ & Saturn, UPCA 1169 \\
\hline CLN 65 & AVRDC & $\mathrm{sp}$ & Saturn, UPCA 1169 , Kewalo \\
\hline CLN 657 & AVRDC & $\mathrm{sp}^{+}$ & Saturn, UPCA 1169 \\
\hline
\end{tabular}

${ }^{2}$ MARDI = Malaysian Agricultural Research and Development Institute; BPI = Bureau of Plant Industry, Philippines; INRA = Institute National de la Recherche Agronomique, France; AVRDC = Asian Vegetable Research and Development Center, Taiwan.

${ }^{\mathrm{y}} \mathrm{sp}=$ determinate, $\mathrm{sp}^{+}=$indeterminate.

'Introduction from AVRDC or a selection from a segregating population sent from the AVRDC but pedigree not known.

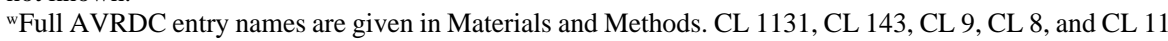
were bred in the 1970s. Remaining CL- or CLN-prefixed lines were bred in the 1980s.

'Venus' and possibly CA-64-1169 were the sources of BW resistance in UPCA 1169 (Mew and Ho, 1977). PI127805A served as the source of BW resistance in 'Kewalo'. PI129080 and Beltsville \#3814 were the sources of BW resistance in 'Venus' and 'Saturn' (Henderson and Jenkins, 1972).

lected at the Malaysian Agricultural Research Institute (Shukor et al., 1989) from segregating populations sent from the AVRDC; Tm 2 is a BW-resistant line from the Bureau of Plant Industry, the Philippines.

Field trials. Field experiments were established at the Subang Horticultural Research Station, Java, Indonesia (lat. 6 ${ }^{\circ}$ 'S and long. $107^{\circ} 8^{\prime} \mathrm{E} ; 110 \mathrm{~m}$ above sea level (masl); volcanic silty clay soil of $\mathrm{pH} 5.3$ ); the Univ. of the Philippines at Los Baños (UPLB), Luzon (lat. $14^{\circ} 11^{\prime} \mathrm{N}$ and long. $121^{\circ} 13^{\prime} \mathrm{E}, 22$ masl, silty clay soil of $\mathrm{pH}$ 5.6); the Malaysian Agricultural Research and Development Institute (MARDI), Kuala Lumpur (lat. $3^{\circ} 0^{\prime} \mathrm{N}$ and long. $101^{\circ} 30^{\prime} \mathrm{E}$; the first replication was done at Jalan Kebun, 3 masl, peat soil of $\mathrm{pH}$ 5.8; replication 2 was done at Serdang, 40 masl, mineral soil of pH 6.4); Taiwan Seed Improvement and Propagation Station (TSIPS), Taichung (lat. $24^{\circ} 12^{\prime} \mathrm{N}$ and long. $120^{\circ} 49^{\prime} \mathrm{E}$, 470 masl, sandy loam soil of $\mathrm{pH}$ 5.7); and the AVRDC, Shanhua, Taiwan (lat. $23^{\circ} 07^{\prime} \mathrm{N}$ and long. $120^{\circ} 17^{\prime} \mathrm{E}, 14$ masl, sandy loam soil of $\mathrm{pH} 7.4$ ).

Before initiation of the field trials at Subang, UPLB, and the AVRDC, the following procedure was performed to increase $P$. solanacearum populations and to promote uniform pathogen distribution. Experimental units consisting of raised beds, $5.2 \mathrm{~m}$ long, and $1 \mathrm{~m}$ wide, with $0.5 \mathrm{~m}$ between beds, were constructed. Three-week-old seedlings of the BW-susceptible tomato accession L390 ('Nan Tzu' from Taiwan) were transplanted to each bed and arranged in four rows, spaced $0.2 \mathrm{~m}$ between and $0.10 \mathrm{~m}$ within rows. When plants were 30 to 35 days old (five- to seven-leaf stage), the upper leaves were cut with knives or scissors and suspensions of a virulent $P$. solanacearum strain $\left[1.6 \times 10^{8}\right.$ to $1 \times 10^{9}$ colony-forming units (cfu)/ml] were applied to the fresh wounds either by spray inoculation or by dipping knives or scissors in the inoculum before wounding. Pseudomonas solanacearum strains used at Subang, UPLB, and the AVRDC to prepare inocula were isolated from diseased tomato plants in the respective countries, and all strains were classified as race 1 biovar 3 . About 2 weeks after inoculation, plants were tilled into the soil and beds were rebuilt at the same positions. At TSIPS and MARDI, entries were transplanted into soil naturally infested with $P$. solanacearum. The experimental field at TSIPS had been used in several previous seasons as a "sick plot" for testing tomato lines for BW resistance (Sunny Chen, personal communication). At MARDI, one nonreplicated trial was established at Jalan Kebun and another nonreplicated trial at Serdang. Since the results from the Malaysian trials were similar (mean BW survival of $97.3 \%$ and $90.0 \%$ at Jalan Kebun and Serdang, respectively), we pooled them, regarding each as a replication for individual location and combined location analyses.

Three-week-old transplants of controls and test accessions were transplanted into the reconstructed beds, except at the AVRDC where seeds of entries were sown directly in the beds. At UPLB and Subang, three 4-m-long rows were established on each bed. Test accessions were located on the two outer rows, $0.2 \mathrm{~m}$ from the side of the bed, and resistant (L285 or Intan Putih) and susceptible (L390) control plants were alternated in the middle row. Spacing between the middle row and outer rows was
$0.3 \mathrm{~m}$, and within-row spacing was $0.2 \mathrm{~m}$. At the AVRDC, MARDI, and TSIPS, only a test accession was transplanted to each bed. Trials were arranged in a randomized complete-block design (RCBD) with two replications at Subang, MARDI, and TSIPS and three replications at UPLB and the AVRDC. Experimental units at all trials included 20 plants of the test entry. The number of wilted plants in each bed was recorded every 7 to 14 days. Stems of wilted plants were cut, placed in water, and examined for bacterial ooze to confirm the presence of $P$. solanacearum.

Duration of field trials was 54 days at Subang (9 Apr.-1 June 1992), 88 days at UPLB (15 Feb.-13 May 1991), 44 days at the AVRDC (14 June-27 July 1994), 62 days at TSIPS (3 Aug.-3 Oct. 1994), and 43 days each at Jalan Kebun (14 July 1993-25 Aug. 1993) and Serdang (6 July 1993-17 Aug. 1993). Total rainfall during the trials ranged from 142 to $547 \mathrm{~mm}$. Mean maxima ranged from 29.5 to $33.5 \mathrm{C}$ and mean minima from 20.0 to $25.2 \mathrm{C}$.

Greenhouse trial. Entries were evaluated for BW resistance in an AVRDC greenhouse with a soil drench inoculation method (AVRDC, 1991). Individual seedlings were grown in plastic pots $(170 \mathrm{ml})$. The potting soil mixture was 1 sand : 3 soil : 1 rice husk : 1 compost with a $\mathrm{pH}$ of $\approx 6.4$. Entries were replicated twice in a RCBD with 24 plants per replication. At 25 days after sowing (fifth trueleaf stage), $20 \mathrm{ml}$ of $10^{8} \mathrm{cfu} P$. solanacearum/ $\mathrm{ml}$ (AVRDC isolate Pss4 from Taiwan) was applied to the base of each plant. Plants were evaluated weekly for wilting for 4 weeks. Mean maxima/minima were $40.9 / 24.2 \mathrm{C}$ in the greenhouse trial.

Data analysis. Final percent entry survival was based on the last evaluation at each trial. Survival data were transformed by arcsin of the square root to normalize the scale before performing analyses of variance (ANOVA). For the combined ANOVA, locations were regarded as random effects and entries as fixed effects; the location $\times$ entry mean square was used to test the significance of the entry mean square and for linear contrasts (McIntosh, 1983). Entry means were separated by the Waller-Duncan test $(\mathrm{k}=100)$. Nonindependent, single-degree-of-freedom contrasts were constructed to make comparisons among groups of entries: 1) CRA 66-derived entries vs. entries with BW resistance derived from UPCA 1169 alone or UPCA 1169 plus 'Venus' or 'Saturn' (all CL- or CLN-prefixed entries except CLN 65); 2) L285 vs. CRA66derived entries; 3) AVRDC lines bred in the 1970s (CL 11, CL 8, CL 9, CL 143, and CL 1131 ) vs. AVRDC lines bred in the 1980s (CL 5915-206, CL 5915-93, CL 6047, CLN 475, CLN 65, and CLN 675).

\section{Results and Discussion}

Conditions were favorable for $\mathrm{BW}$ in the field tests based on the near $0 \%$ survival of the susceptible control, L390 (Table 2). Mean survival of entries, excluding L390, was dramatically less at Subang and UPLB (21.6\% and $31.9 \%$, respectively) than in the Malay- 
Table 2. Bacterial wilt reactions of tomato entries evaluated at five southeast Asian locations and a greenhouse in Taiwan.

\begin{tabular}{|c|c|c|c|c|c|c|}
\hline \multirow[b]{2}{*}{ Entry } & \multicolumn{6}{|c|}{ Survival (\%) } \\
\hline & Subang, Indonesia & UPLB, Philippines $^{\mathrm{z}}$ & AVRDC, Taiwan ${ }^{2}$ & TSIPS, Taiwan ${ }^{z}$ & MARDI, Malaysiaz & Greenhouse \\
\hline L285 & $75.3 \mathrm{a}^{\mathrm{y}}$ & $68.1 \mathrm{a}$ & $89.6 \mathrm{a}-\mathrm{d}$ & $93.8 \mathrm{ab}$ & $97.0 \mathrm{ab}$ & $95.9 \mathrm{a}-\mathrm{c}$ \\
\hline CRA 84-58-1 & $52.5 \mathrm{ab}$ & $66.0 \mathrm{ab}$ & $84.9 \mathrm{~b}-\mathrm{d}$ & $100.0 \mathrm{a}$ & $97.5 \mathrm{ab}$ & $100.0 \mathrm{a}$ \\
\hline CRA 84-79 & $45.8 \mathrm{bc}$ & $53.6 \mathrm{a}-\mathrm{c}$ & $98.3 \mathrm{a}$ & $100.0 \mathrm{a}$ & $100.0 \mathrm{a}$ & $97.9 \mathrm{ab}$ \\
\hline CLN 65 & $42.1 \mathrm{bc}$ & $43.6 \mathrm{a}-\mathrm{d}$ & $90.9 \mathrm{a}-\mathrm{d}$ & $96.5 \mathrm{a}$ & $100.0 \mathrm{a}$ & $83.4 \mathrm{de}$ \\
\hline MT5 & $32.9 \mathrm{~b}-\mathrm{d}$ & $37.5 \mathrm{~b}-\mathrm{f}$ & $92.7 \mathrm{a}-\mathrm{c}$ & $100.0 \mathrm{a}$ & $95.0 \mathrm{ab}$ & $93.8 \mathrm{a}-\mathrm{d}$ \\
\hline CRA 84-6-3 & $30.4 \mathrm{~b}-\mathrm{d}$ & $0.0 \mathrm{~h}$ & $75.7 \mathrm{~d}-\mathrm{f}$ & $100.0 \mathrm{a}$ & $100.0 \mathrm{a}$ & $76.4 \mathrm{~d}-\mathrm{f}$ \\
\hline CLN 475 & $27.5 \mathrm{c}-\mathrm{e}$ & $32.6 \mathrm{c}-\mathrm{f}$ & $86.0 \mathrm{~b}-\mathrm{d}$ & $100.0 \mathrm{a}$ & $100.0 \mathrm{a}$ & $89.2 \mathrm{a}-\mathrm{d}$ \\
\hline MT10 & $27.3 \mathrm{c}-\mathrm{e}$ & $64.8 \mathrm{ab}$ & $94.8 \mathrm{ab}$ & $93.8 \mathrm{ab}$ & $100.0 \mathrm{a}$ & $73.0 \mathrm{ef}$ \\
\hline CL 5915-93 & $24.2 \mathrm{c}-\mathrm{e}$ & $59.6 \mathrm{a}-\mathrm{c}$ & $79.0 \mathrm{c}-\mathrm{f}$ & $100.0 \mathrm{a}$ & $97.5 \mathrm{ab}$ & $87.1 \mathrm{~b}-\mathrm{e}$ \\
\hline $\operatorname{Tm} 2$ & $15.3 \mathrm{~d}-\mathrm{f}$ & $53.6 \mathrm{a}-\mathrm{c}$ & $92.3 \mathrm{a}-\mathrm{c}$ & $95.5 \mathrm{a}$ & $97.5 \mathrm{ab}$ & 70.8 ef \\
\hline Caraïbo & $15.3 \mathrm{~d}-\mathrm{f}$ & $43.3 \mathrm{a}-\mathrm{e}$ & $86.9 \mathrm{a}-\mathrm{d}$ & $100.0 \mathrm{a}$ & $90.5 \mathrm{ab}$ & $87.5 \mathrm{~b}-\mathrm{e}$ \\
\hline CRA 84-26-3 & $12.8 \mathrm{~d}-\mathrm{h}$ & $47.7 \mathrm{a}-\mathrm{d}$ & $94.6 \mathrm{ab}$ & $100.0 \mathrm{a}$ & $82.5 \mathrm{~b}$ & 74.6 ef \\
\hline CL 5915-206 & $10.2 \mathrm{e}-\mathrm{h}$ & $13.0 \mathrm{f}-\mathrm{g}$ & $79.5 \mathrm{c}-\mathrm{e}$ & $78.5 \mathrm{bc}$ & $95.0 \mathrm{ab}$ & $76.6 \mathrm{~d}-\mathrm{f}$ \\
\hline CL 1131 & $5.7 \mathrm{f}-\mathrm{i}$ & $11.1 \mathrm{f}-\mathrm{g}$ & $55.9 \mathrm{fg}$ & $100.0 \mathrm{a}$ & $90.0 \mathrm{ab}$ & $56.3 \mathrm{fg}$ \\
\hline CL 143 & $5.5 \mathrm{f}-\mathrm{i}$ & $16.9 \mathrm{e}-\mathrm{h}$ & 80.8 b-e & $100.0 \mathrm{a}$ & $97.5 \mathrm{ab}$ & 89.4 b-d \\
\hline CL 9 & $3.4 \mathrm{~g}-\mathrm{i}$ & $0.1 \mathrm{~h}$ & $58.7 \mathrm{e}-\mathrm{g}$ & $74.0 \mathrm{c}$ & $91.5 \mathrm{ab}$ & $84.2 \mathrm{c}-\mathrm{e}$ \\
\hline CL 6047 & $2.8 \mathrm{hi}$ & $0.0 \mathrm{~h}$ & $38.1 \mathrm{gh}$ & $59.7 \mathrm{c}$ & $82.5 \mathrm{~b}$ & $31.3 \mathrm{gh}$ \\
\hline CL 8 & $2.5 \mathrm{hi}$ & $7.1 \mathrm{gh}$ & $50.5 \mathrm{~g}$ & $97.0 \mathrm{a}$ & $81.0 \mathrm{~b}$ & $83.4 \mathrm{de}$ \\
\hline CLN 657 & $0.0 \mathrm{i}$ & $16.8 \mathrm{~d}-\mathrm{g}$ & $79.6 \mathrm{~b}-\mathrm{e}$ & $100.0 \mathrm{a}$ & $95.0 \mathrm{ab}$ & 74.2 ef \\
\hline CL 11 & $0.0 \mathrm{i}$ & $1.0 \mathrm{~h}$ & $25.4 \mathrm{~h}$ & $78.0 \mathrm{bc}$ & $82.5 \mathrm{~b}$ & $57.7 \mathrm{f}$ \\
\hline L390 (susceptible) $^{\mathrm{x}}$ & & $1.0 \mathrm{~h}$ & $0.0 \mathrm{i}$ & $0.0 \mathrm{~d}$ & $1.5 \mathrm{c}$ & $17.1 \mathrm{~h}$ \\
\hline Trial mean & 21.6 & 31.9 & 76.7 & 93.3 & 93.6 & 79.1 \\
\hline
\end{tabular}

${ }^{2}$ UPLB $=$ Univ. of the Philippines at Los Baños; AVRDC $=$ Asian Vegetable Research and Development Center; TSIPS $=$ Taiwan Seed Improvement and Propagation Service; MARDI = Malaysian Agricultural Research and Development Institute.

y Mean separation by Waller-Duncan $(\mathrm{k}$ ratio $=100$ ). Data were transformed to the arcsin of the square root for analysis.

${ }^{\times}$L390 not included as an entry in the Subang trial.

sian and Taiwan trials $(93.6 \%, 76.7 \%$, and 93.3\% survival at MARDI, the AVRDC, and TSIPS, respectively). Thus, most entries were resistant at MARDI, the AVRDC, and TSIPS, but susceptible at Subang and UPLB. BW was particularly severe at Subang, considering the shorter duration of the experiment (54 days), than at Los Baños (88 days). We cannot ascertain the reasons for the entry survival differences among locations. Variation among locations in soil type and $\mathrm{pH}$, as well as rainfall and temperatures during trials, also may have affected host resistance (Hayward, 1991; Messiaen, 1989). Pseudomonas solanacearum strains also varied among locations. Several researchers have demonstrated virulence differences among $P$. solanacearum strains (Elphinstone, 1994; Lopes et al., 1994; Prior et al., 1990). Elphinstone (1994) identified one race 3/biovar 2 strain isolated from potato (Solanum tuberosum L.) in Indonesia that caused wilting in 'Venus', 'Saturn', UPCA 1169, 'Caraïbo', 'Kewalo', as well as other BW-resistant entries.

ANOVA over locations (Table 3 ) detected significant differences among entries for BW resistance. L285 and CRA 84-58-1 were the most consistently resistant entries over the five locations (Table 2). CL 11, CL 9, and CL 6047 , however, ranked among the least resistant entries at most locations. Eleven, 16, and 20 entries at the AVRDC, TSIPS, and MARDI, respectively, showed mean survival $>80 \%$, but all entries fell to $<80 \%$ survival at Subang and UPLB. Rank changes and magnitude differences among trials (Table 2) apparently accounted for the highly significant location $x$ entry interaction in the ANOVA (Table 3). When the Subang and UPLB trials were analyzed together without the other trials, a significant location $\times$ entry effect was found (data not shown), but generally, the most resistant entries at Subang also were the most resistant at UPLB. Mean survival of CRA 66-derived entries $(70.1 \%)$ was significantly greater than the mean survival of entries with resistance derived from UPCA 1169 alone or UPCA 1169 plus 'Venus' or 'Saturn' (53.2\%) (Table 3 , contrast no. 1). Mean survival of L285 was not significantly greater than the group mean of CRA 66-derived lines (contrast no. 2).

'Saturn', 'Venus', and VC-prefixed lines from the Philippines were the most frequently used sources of BW resistance at the AVRDC (Opeña et al., 1989). UPCA 1169, a selection from 'Venus' x CA-64-1169 (Mew and Ho, 1977), was the BW resistance source for VC lines, such as VC 48-1 and VC 8-1-2-7, found in the pedigrees of numerous AVRDC tomato lines. We do not know the $\mathrm{BW}$ reaction of CA64-1169. PI406994 (L. esculentum from Panama), L366 (L. esculentum of unknown origin), and lines bred at the Univ. of Hawaii derived from PI127805A were additional BW resistance sources used to a lesser extent at the AVRDC (AVRDC, 1973; Opeña et al., 1989). BW-resistant lines derived from PI127805A were not exploited extensively at the AVRDC, apparently because resistance from this source was thought to be unstable at high temperatures (Yang, 1979). The group survival mean of AVRDC lines bred in the 1980s was significantly higher than the mean of 1970s lines, indicating progress in BW-resistance selection (contrast no. 3). However, the BW resistance in most of the AVRDC entries was derived from related sources (Table 1), and progress possibly could be improved by including new resistance sources as parents.

An objective of the AVRDC Tomato Improvement Project is the development of $\mathrm{BW}$ resistant lines with $>90 \%$ survival. Most entries in this experiment, including the AVRDC lines, performed well in the Malaysian and Taiwan trials and in an additional trial in Thailand (Thaveechai et al., 1994). However, no entry in this experiment achieved $>90 \%$ survival at Subang or UPLB. Since this experiment included representatives of only several of the available sources of BW resistance, it would be useful to evaluate additional entries from a broader range of $\mathrm{BW}$ resistance sources, especially at Subang and UPLB. More field evaluations of BW-resistant cultivars are needed to more clearly delineate those areas where BW is particularly severe. The resistance in many of the entries evaluated in this experiment might be deployed to places where $\mathrm{BW}$ is less severe. To develop varieties for regions where $\mathrm{BW}$ is severe, new sources of $\mathrm{BW}$ resistance must be found, possibly in the wild tomato species, or diverse BW-resistance sources must be combined with the objective of achieving higher resistance levels (Scott et al., 1993). Improvement of BW resistance in AVRDC lines may be achieved by crossing with CRA 66 derivatives, such as CRA 84-58-1, followed by multi-location testing and selection. Although most CRA lines carry excellent BW resistance and are relatively large-fruited (100 to $250 \mathrm{~g}$ fruit size in the cool season), most need improvement for hightemperature fruit set.

L285 is a potential source of new BW resistance genes. L285 has been included as a resistant control in AVRDC BW experiments for many years. However, resistance genes in L285 have not been exploited at the AVRDC because of an assumed linkage between genes conditioning BW resistance and small fruit size (Opeña et al., 1990). L285 possesses at least two loci involved in BW resistance (Danesh et al., 1994) and linkage analysis detected no association between genes conditioning fruit size and loci controlling resistance to $P$. solanacearum strain UW-364 (N.D. Young, unpublished data). Results of BW evaluation (strain Pss4) of recombinant inbreds derived from L285 indicated an associa- 
Table 3. Mean squares (MS) from the combined analysis of variance and contrasts of tomato entries evaluated for bacterial wilt reaction in southeast Asia.

\begin{tabular}{lrr}
\hline \hline Source of variation & df & MS \\
\hline Survival & \\
Locations & 4 & $33260.3^{* *}$ \\
Entries & 19 & $1652.9^{* *}$ \\
Location $\times$ entries & 76 & $226.3^{* *}$ \\
Contrasts & 1 & $7613.4^{* *}$ \\
\#1CRA 66-derived (70.1) vs. PI129080-derived (53.2) & 1 & $430.5^{\text {ss }}$ \\
\#2 L285 (83.8) vs. CRA (70.1) & 1 & $3507.5^{* *}$ \\
\#3 AVRDC: 1970 s (45.7) vs. 1980s (59.4)
\end{tabular}

${ }^{2}$ Data were transformed to the arcsin of the square root for analysis.

${ }^{y}$ Number in parentheses is the group mean for percent survival.

Ns, **Nonsignificant or significant at $P \leq 0.01$, respectively.

tion between fruit size and BW resistance (P.M.H. and J.-F.W., unpublished data).

Routine BW screening at the AVRDC since 1991 has been performed by drench inoculation of tomato lines in the greenhouse with a virulent strain of $P$. solanacearum (Pss4) from Taiwan (AVRDC, 1991). During the past 20 years, the AVRDC tomato project researchers have tried several BW inoculation techniques, including leaf clipping and stem puncture. Most of these techniques were too severe and did not clearly differentiate resistant and susceptible entries (AVRDC, 1991; Opeña et al., 1990). The leaf-clipping method is particularly severe; in one experiment, mean BW survival of L285 was only $20 \%$ with this inoculation technique (AVRDC, 1991). Drench inoculation is less severe than leaf clipping or stem puncture. In our study, the correlation between BW entries averaged over field trials and entry means from drench inoculation in the greenhouse was highly significant $(r=$ 0.70 ), which suggests that the drench method is fairly effective in selection for BW resistance in the field. Compared to field BW screening, the drench method is cheaper and results are available more quickly. Effective BW screening with the drench method requires high temperatures. When greenhouse day temperatures are maintained at 30 to $35 \mathrm{C}$ and $>25 \mathrm{C}$ at night, we have observed that most susceptible plants wilt within 2 weeks.

Detection of susceptible lines and entries with low BW resistance, such as CL 6047 or CL 11, is probable at the AVRDC by drench inoculation with Pss4. However, AVRDC screening may not detect lines such as CL 143 or CL 5915-206, which show locationspecific resistance. Recent evidence shows that host loci conferring BW resistance vary in importance, depending on $P$. solanacearum strain. Genes at loci on chromosomes 6 and 10 condition resistance against $P$. solanacearum strain UW-364, but these loci were not important in resistance to Pss4 (Danesh and Young, 1994). BW screening at the AVRDC could be improved by inoculating plants with a combination of selected pathogen strains, such as Pss4 and UW-364, which would apply selection pressure to genes at a wider range of host loci compared to either strain alone. Establishment of a two-stage testing program where entries resistant at the AVRDC are sent to the Philippines and Indonesia for further evaluation could help identify less-resistant entries.

Overcoming BW is a common objective of all southeast Asian tomato breeding programs. Research networks such as the Collaborative Vegetable Research Program are valuable in the facilitation of linkages among BW researchers, development of common research protocols, and exchange of germplasm. As our collaboration continues in the future, we hope to speed the development of BW-resistant tomato varieties, as well as improve our understanding of the regional BW situation.

\section{Literature Cited}

Asian Vegetable Research and Development Center. 1973. Progress report. Asian Veg. Res. and Dev. Ctr., Shanhua, Tainan, Taiwan. p. 31-32.

Asian Vegetable Research and Development Center. 1978. Progress report. Asian Veg. Res. and Dev. Ctr., Shanhua, Tainan, Taiwan. p. 13.

Asian Vegetable Research and Development Center. 1991. Progress report. Asian Veg. Res. and Dev. Ctr., Shanhua, Tainan, Taiwan. p. 188 193.

Asian Vegetable Research and Development Center. 1992. Translating strategy into action: An action plan for 1993-1997. Asian Veg. Res. and Dev. Ctr., Shanhua, Tainan, Taiwan. p. 18-19.

Chellemi, D.O., H.A. Dankers, S.M. Olson, N.C. Hodge, and J.W. Scott. 1994. Evaluating bacterial wilt-resistant tomato genotypes using a regional approach. J. Amer. Soc. Hort. Sci. 119:325-329.

Danesh, D., S. Aarons, G.E. McGill, and N. Young. 1994. Genetic dissection of oligogenic resistance to bacterial wilt in tomato. Mol. Plant-

Danesh, D. and N. Young. 1994. Partial resistance loci for bacterial wilt show differential race specificity. Rpt. Tomato Genet. Coop. 44:1213.

Elphinstone, J.G. 1994. Virulence of isolates of Pseudomonas solanacearum from worldwide sources on resistant and susceptible tomato cultivars, p. 599-604. In: Institute National de la Recherche Agronomique (ed.). Proc. 8th Intl. Conf. Plant Pathogenic Bacteria. Institut National de la Recherche Agronomique, Paris

Gilbert, J.C., J.S. Tanaka, and K.Y. Takeda. 1973. 'Kewalo' tomato. HortScience 9:481-482.

Grimault, V., J. Schmit, and P. Prior. 1993. Some characteristics involved in bacterial wilt (Pseudomonas solanacearum) resistance in toMicrobe Interactions 7:464-471. mato, p. 112-119. In: G.L. Hartman and A.C. Hayward (eds.). Bacterial wilt. Australian Ctr. Intl. Agr. Res. Proc. 45.

Hayward, A.C. 1991. Biology and epidemiology of bacterial wilt caused by Pseudomonas solanacearum. Annu. Rev. Phytopathol. 29:6587.

Henderson, W.R. and S.F. Jenkins, Jr. 1972. 'Venus' and 'Saturn', tomato varieties resistant to southern bacterial wilt. HortScience 7:346.

Jaworski, C.A., S.C. Phatak, S.R. Ghate, R.D. Gitaitis, and M.P. Widrlechner. 1987. GA 15652-4 BWT, GA 219-1-2 BWT, GA 1095-1-4 BWT, and GA 1405-1-2 BWT bacterial wilttolerant tomato. HortScience 22:324-325.

Krausz, J.P. and H.D. Thurston. 1975. Breakdown of resistance to Pseudomonas solanacearum in tomato. Phytopathology 65:1272-1274.

Libman, G., J.G. Leach, and R.E. Adams. 1964. Role of certain plant-parasitic nematodes in infection of tomatoes by Pseudomonas solanacearum. Phytopathology 54:151-153.

Lopes, C.A., A.M. Quezado-Soares, and P.E. De Melo. 1994. Differential resistance of tomato cultigens to biovars I and III of Pseudomonas solanacearum. Plant Dis. 78:1091-1094.

McIntosh, M.S. 1983. Analysis of combined experiments. Agron. J. 75:153-155.

Messiaen, C.M. 1989. Environmental influences on the severity of tomato bacterial wilt in the French West Indies: Interactions with varietal resistance, p. 235-238. In: S.K. Green (ed.). Tomato and pepper production in the tropics. Asian Veg. Res. and Dev. Ctr., Shanhua, Taiwan.

Mew, T.W. and W.C. Ho. 1977. Effect of soil temperature on resistance of tomato cultivars to bacterial wilt. Phytopathology 67:909-911.

Opeña, R.T, S.K. Green, N.S. Talekar, and J.T. Chen. 1989. Genetic improvement of tomato adaptability to the tropics: Progress and future prospects, p. 70-85. In: S.K. Green (ed.). Tomato and pepper production in the tropics. Asian Veg. Res. and Dev. Ctr., Shanhua, Taiwan.

Opeña, R.T, G.L. Hartman, J.T. Chen, and C.H. Yang. 1990. Breeding for bacterial wilt resistance in tropical tomato, p. 44-50. In: Proc. 3rd Intl. Conf. Plant Protection in the Tropics. Genting Highlands, Malaysia.

Prior, P., H. Steva, and P. Cadet. 1990. Aggressiveness of strains of Pseudomonas solanacearum from the French West Indies (Martinique and Guadeloupe) on tomato. Plant Dis. 74:962965.

Scott, J.W., G.C. Somodi, and J.B. Jones. 1993. Testing tomato genotypes and breeding for resistance to bacterial wilt in Florida, p. 126-131. In: G.L. Hartman and A.C. Hayward (eds.). Bacterial wilt. Australian Ctr. Intl. Agr. Res. Proc. 45.

Shukor, N.M., B.H. Chew, S. Noraini, and M.N.M. Roff. 1989. Tomato and chili pepper growing in Malaysia, p. 508-520. In: S.K. Green (ed.). Tomato and pepper production in the tropics. Asian Veg. Res. and Dev. Ctr., Shanhua, Taiwan.

Thaveechai, N., W. Kositratana, and C.Leksomboon. 1994. Bacterial wilt of tomato in Thailand, $p$. 305-315. In: C. Bejosano-Gloria (ed.). Collaborative vegetable research in Southeast Asia. Asian Veg. Res. and Dev. Ctr., Shanhua, Taiwan.

Yang, C.Y. 1979. Bacterial and fungal diseases of tomato, p. 111-123. In: R. Cowell (ed.). First Intl. Symp. on Tropical Tomato. Asian Veg. Res. and Dev. Ctr., Shanhua, Taiwan. 